Jurnal Indonesia Sosial Teknologi: p-ISSN: 2723 - 6609

e-ISSN : 2745-5254

Vol. 2, No. 2 Februari 2021

\title{
HERE TO HEAR : METODE THERAPYS GROUP DALAM PROSES MENTAL HEALTH ATTENTION UNTUK MENANGANI STRESS MAHASISWA AKIBAT STUDY FROM HOME DI TENGAH PANDEMI
}

\author{
Refki Rizki Alfani, Muhamad Rafi Abdul Rasyd dan Mochamad Ravi Adia \\ Pramesti \\ Politeknik Negeri Bandung, Indonesia \\ Email: refki.rizki.mpem419@polban.ac.id, muhamad.rafi.mpem419@polban.ac.id dan \\ mochamad.ravi.tele418@polban.ac.id
}

\begin{abstract}
The COVID-19 virus outbreak has made significant changes to people's lifestyles. Included in the learning process. Students especially, should study online. So based on research shows that many students experience stress, as a result students need movements or programs that provide mental training. The research method in this study uses a qualitative method, namely through literature studies, by combining the theory of group therapy and mental health attention. Also presented are solutions in the form of experimental actions, such as motivational approaches, therapy, and mentoring to increase students' sense of calm in dealing with stress. In addition, the purpose of this study is to integrate psychological methods with technology.
\end{abstract}

Keywords: mental; stress; health attention; therapys group.

\begin{abstract}
Abstrak
Wabah virus COVID-19 telah membuat perubahan signifikan pada gaya hidup manusia. Termasuk dalam proses pembelajaran. Siswa khususnya, harus belajar daring. Sehingga berdasarkan penelitian menunjukkan bahwa banyak siswa yang mengalami stres, akibatnya mahasiswa membutuhkan gerakan atau program yang memberikan pelatihan mental. Metode penelitian dalam penelitian ini menggunakan metode kulitatif, yakni melalui studi pustaka, dengan menggabungkan teori terapi kelompok dan perhatian kesehatan mental. Disajikan pula solusi berupa tindakan eksperimental, seperti pendekatan motivasi, terapi, dan juga mentoring untuk meningkatkan rasa tenang pada mahasiswa dalam mengatasi stres. Selain itu, tujuan dari penelitian ini juga mengintegrasikan antara metode psikologi dengan teknologi.
\end{abstract}

Kata kunci: mental; tekanan; perhatian kesehatan; kelompok terapis. 
Here To Hear: Metode Therapys Group dalam Proses Mental Health Attention untuk Menangani Stress Mahasiswa

\section{Pendahuluan}

Merebaknya wabah virus COVID-19 pada Maret 2020 di Indonesia menciptakan perubahan signifikan pada dunia pendidikan. Pembelajaran melalui media daring atau dikenal dengan e-learning ini belum sepenuhnya baik. Hal ini diamini oleh Nadiem Makarim, selaku Menteri Pendidikan dan Kebudayaan Indonesia, beliau mengatakan aktivitas pembelajaran di masa darurat seperti ini belum optimal (Purandina, 2020). Ketidakoptimalan ini juga terasa di perguruan tinggi, alhasil menciptakan suasana penuh tekanan terhadap mahasiswa. Mahasiswa disesaki dengan beban tugas juga masalah lain akibat study from home yang tidak efektif. Peneliti Universitas Padjajaran menemukan 47\% mahasiswa mengalami depresi di masa pandemi COVID-19, banyak diantara mereka terkena gejala depresi akibat beban tugas menumpuk, gagal beradaptasi, hingga kebingungan dengan kejar target tugas akhir (Florensa, Keliat, \& Wardani, 2016).

Selanjutnya, menurut Diana Setiawayati peneliti dari Center of Public Mental Health Psikologi Universitas Gajah Mada memprediksikan bahwa 15-25\% mahasiswa membutukan mental health attention (perhatian lebih untuk mengatasi masalah kesehatan mental). Dari 10.000 mahasiswa, sekiranya ada 2000 mahasiswa yang memerlukan mental health attention. Kondisi ini sudah diwanti-wanti oleh Centers for Disease Control and Prevetion (CDC) yang mengatakan bahwa pandemik ini beresiko memunculkan ganguan mental, gangguan depresi dan kecemasan di masyarakat. Bahkan, lebih buruknya efek depresi ini menurut Prof. Rory o'Connnori dari Universitas Glasgow dapat membuat seseorang melakukan perilaku negatif seperti mengonsumsi alkohol dan narkoba. Ditambahkan oleh WHO (2019) stress di masa pandemi juga dapat berupa, Menurut WHO (2019), stres yang muncul selama masa pandemi COVID-19 dapat memperparah fisik orang yang memiliki penyakit kronis, sulit tidur dan konsesntrasi dan perubahan pola tidur dan pola makan ( $\mathrm{Zu}$ et al., 2020).

Untuk itu dibutuhkan program yang dapat menunjang kesehatan mental mahasiswa saat melakukan study from home. Namun, tentu sebagai mahasiswa, mereka tidak memiliki waktu untuk sekadar berkonsultasi kepada psikiater apalagi jika berbayar. Mahasiswa disibukan dengan tumpukan tugas, belum lagi mahasiswa tingkat akhir yang disibukan dengan riset, observasi, pengetikan bahan skripsi dan lain-lain. Hal ini membuat mereka tidak punya pilihan. Maka dari itu, metode terbaik memberikan pelayanan kesehatan mental pada mahasiswa harus dilakukan secara dor-to-dor dengan meraih banyak partisipan secara kolektif agar waktu bisa efisien. Selain itu, program yang dihadirkan wajib terstruktur agar menghasilkan output yang diinginkan.

Dalam hal gagasan yang diajukan akan berfokus pada penerapan metode psikologi yang sudah ada namun, dipadukan dengan kegiatan yang kreatif. Dikutip dari Departemen Piskologi Klinis (UNAIR, 2020), bahwa program yang cocok untuk mengatasi stress masa pandemi adalah mental health attention untuk self healing dalam hal ini berupa kegiatan seperti mindfulness (penyegaran pikiran), guided imagenery (membayangkan sesuatu yang menyenangkan), self talk (berbicara pada diri sendiri secara positif), expressive writing (refleksikan pikiran dan perasaan). Namun hal ini, 
dianggap belum cukup, karena jika ita merujuk pada Maslow Hierarchy Needs, memiliki kebutuhan sosial atau social needs tentunya akan membutuhkan keterlibatan orang lain untuk saling menguatkan di masa pandemi. Maka dibutuh metode terapi healing yang dirancang group to group dalam proses mengatasi terapi akibat stress (Arroisi, 2018).

Terapi kelompok adalah treatment yang dilakukan dengan proses menyertakan orang dalam kelompok kecil tertentu yang disertai pendamping. Tujuan terapi ini untuk meningkatkan ketenangan batin, dengan pendekatan kognitif dan efektif (Bahrien \& Ardianty, 2017).

Maka dari itu, gagasan tertulis ini mengajukan suatu program. Rencananya program ini bernama here to hear adalah program terorganisasi periodik menggunakan metode grup terapi yang dilakukan untuk melakukan mentorisasi kepada mahasiswa dalam mengatasi masalah kesehatan mental ketika masa pandemi Covid-19. Program here to hear ini akan berkolaborasi dengan lembaga bimbingan konseling kampus dan organisasi peer conselor (mahasiswa yang berwenang menjadi konselor psikologis mahasiswa) (Mufarida, 2020). Secara singkat, terapi grup adalah program yang dibarengi dengan tutor-tutor terlatih yang akan mengarahkan mahasiswa untuk melakukan berbagai aktivitas positif dan produktif mengatasi masalah kesehatan mental mereka. Tentunya, program ini juga kurikulumnya akan diarahkan oleh psikolog yang ahli di bidangnya.

\section{Metode Penelitian}

metode kulitatif, yakni melalui studi pustaka, dengan menggabungkan teori terapi kelompok dan perhatian kesehatan mental. Disajikan pula solusi berupa tindakan eksperimental, seperti pendekatan motivasi, terapi, dan juga mentoring untuk meningkatkan rasa tenang pada mahasiswa dalam mengatasi stress.

\section{Hasil dan Pembahasan}

\section{Solusi yang Pernah Ditawarkan}

Dalam kasus ini, terdapat beberapa upaya yang pernah dilakukan demi menunjang kesehatan mental mahasiswa. Salah satunya dilakukan oleh Unit Pelayanan Terpadu Bimbingan, Konseling dan Pendampingan yang biasa disebut UPT BKP ialah salah satu badan yang mengupayakan pembenahan mental bagi mahasiswa. Dengan berbagai program yang dinamis, unit ini dibantu oleh sekelompok mahasiswa yang bersedia menjadi tutor sebaya (peer conselor). Perlu dicatat, masih banyak mahasiswa yang belum sadar akan adanya unit ini, maka dari itu diperlukan upaya-upaya sosialisasi agar informasi baik ini dapat terdengar bagi seluruh mahasiswa. Selain itu, upaya lain yang sudah digalakan adalah maraknya platform daring untuk menangani kesehatan mental. Selain mudah dan efisien, media ini menjadi solusi karena pengguna platform ini bisa mengakses dimanapun ia berada atau fleksibel. Platform ini pun sudah ada di berbagai universitas ternama, salah satunya rumah empati web daring yang dikembangkan dosen UGM. Namun kekurangan media ini ialah tidak sepenuhnya 
daerah di indonesia yang memiliki jaringan internet, selain itu sinyal yang tidak stabil dapat mengganggu jalannya konsultasi.

Untuk melengkapi solusi yang sudah ditawarkan maka, berikut adalah konsep gagasan yang diajukan :

a. Merancang program mental health attention untuk menunjang beban Ketika study from home berupa program terorganisasi, rediri dari mentorisasi, aplikasi, dan evaluasi yang dilakukan secara bertahap, kegiatan dari tingkat prodi, jurusan, hingga tingkat universitas.

\section{Mentorisasi}

Program ini akan dimulai dengan pembagian kelompok tutor yang mengedukasi suatu kelompok mahasiswa. Metode penyembuhan psikologi dalam hal ini akan disesuaikan dengan masalah masing-masing mahasiswa dihitung dari masalah yang paling banyak muncul. Mentoring yang akan dilakukan yakni melalui mentoring metode informal casual dengan penerapannya lebih.

Selanjutnya, mentoring dari segi tujuannya lebih kepada mentoring personal development atau pengembangan diri sedangkan medianya menggunakan internet mentoring atau melalui basis teknologi komunikasi berbasis internet. Dari segi jumlah partisipan yakni group mentoring atau berkelompok. Dalam naskah publikasi (Mariana, 2017 ) menuliskan bahwa salah satu cara melakukan pemberdayaan terhadap suatu kelompok dengan merancang dan melaksanakan program mentorisasi. Artinya diberikan upaya mentorisasi kepada kelompok mahasiswa nantinya.

\section{Aplikasi}

Mahasiswa pada fase aplikasi akan dituntun menerapkan metode-metode psikologi yang dipilih, tentunya dengan cara yang menyenangkan tidak memberatkan seperti halnya beban tugas kuliah. Langkah konkrit yang diterapkan dalam fase aplikasi ini dengan menggunakan tren-tren yang sedang digandrungi anak muda untuk menyenangkan mereka. Ada beberapa tahapan dalam fase aplikasi ini, dibagi atas dua penerapan terapi, yakni terapi aktivitas dan terapi meditasi/zikir:

Terapi aktivitas :

a. Pembiasaan keagamaan.

Pelayanan keagamaan adalah metode paling efektif untuk membangun mentalitas mahasiswa. Tentunya dalam aktivitas ini akan ada kolaborasi antara UKM/organisasi keagamaan kampus dan dosen rohani kampus dengan tim here to hear. Contoh sederhana dalam aktvitas ini adalah tantangan/challenge yang bernuansa keagamaan namun tentunya tidak memberatkan.

b. Pembinaan fisik dan permainan.

Terapi ini bermanfaat untuk menjaga imun tubuh mahasiswa di tengah pandemi. Bagi mahasiswa yang kesehariaannya jarang berolahraga, pembinaan fisik ini akan mengarahkan siswa untuk menjaga fisik mereka sesuai kemampuan, mengajak mereka untuk beberapa menit meluangkan 
waktu untuk melatih otot-otot tubuh. Sedangkan untuk permainan, mahasiswa akan diajak bermain games yang sedang tren dikalangan anak muda bisa berupa games di media sosial (Fahrurrozi, 2019).

c. Pembinaan mental dan psikologis

Pada proses ini mahasiswa akan diajak melakukan self healing atau penyembuhan diri dengan metode-metode sesuai anjuran ahli psikologi. Selain itu, ada pembekalan tentang budi pekerti, hidup sehat, atau konsultasi serta materi motivasi.

d. Bimbingan Sosial

Mahasiswa akan disentuh untuk responsif dengan kondisi sosial di tengah pandemi akan masalah-masalah di masyarakat (Shadiq, 2020). Bisa berupa diskusi, konseling, bakti sosial atau pun kajian pemecahan masalah sesuai dengan minat mereka.

e. Pembinaan Keterampilan

Pada tahap ini, mahasiswa akan diarahkan untuk lebih mengasah kemampuan bakat. Mahasiswa akan diajak memahami passion, reiki positif, atau ikigai masing- masing. Tentunya dengan panduan-panduan yang terpadu dan terintegrasi. Memahami apa itu passion sangat menarik. Dalam skripsi (Nurjahnah, 2018) didapatkan hasil terdapat hubungan antara passion dengan komitmen profesi. Maka, degan mahasiswa mengetahui passsion dapat menjadi bekal positif nantinya dalam berkomitmen terhadap profesi.

Terapi Meditasi :

Secara teknik, terapi ini hampir mirip perenungan diri dalam kurun waktu tertentu.

\section{Evaluasi}

Dalam tahap ini adalah bentuk pengawasan kepada mahasiswa untuk setiap kegiatan $\mathrm{H} 2 \mathrm{H}$. Pengawasan $\mathrm{H} 2 \mathrm{H}$ (Here to Hear) ini, mahasiswa akan diawasi oleh mentor terlatih. Di akhir kegiatan, seluruh mahasiswa yang terlibat akan diarahkan membuat satu karya menarik hasil dari bimbingan di $\mathrm{H} 2 \mathrm{H}$ ini.

\section{Pengembangan Teknologi}

Menambahkan teknologi web atau aplikasi mental health attention yang menjadi sarana mahasiswa konseling, belajar dan mengikuti tips-tips mengatasi masalah depresi akibat pandemi Covid-19. Web atau aplikasi $\mathrm{H} 2 \mathrm{H}$ ini sebetulnya hanya pendukung saja untuk menjadi tempat konseling, hanya saja diferensiasinya web ini bisa menjadi alat pengawas pada setiap tahapan-tahapan program $\mathrm{H} 2 \mathrm{H}$ dilaksanakan.

\section{Pihak yang Membantu untuk Mengimplementasikan Gagasan}

Gagasan here to hear ini tentu akan terwujud apabila adanya dukungan dari beberapa pihak :

\section{a. Direktorat Kemahasiswaan}


Direktorat kemahasiswaan memiliki peran vital dalam menjalankan program ini. Karena nantinya akan menjadi penangung jawab setiap rangkaian kegiatan. Dalam prosesnya, direktorat kemahasiswaan, akan ikut merancang bersama kegiatan ini, dengan melibatkan perwakilan badan eksekutif mahasiswa dan tutor-tutor psikologis dari UPT Badan Konseling dan Psikologi Mahasiswa di Perguruan Tinggi. Direktorat juga bertanggung jawab atas segala dana yang digunakan, itulah alasan program ini perlu dimasukan ke dalam RAK dan RAB satu tahun periode. Selain dana, direktorat juga memberikan tugas kepada staf-stafnya menjadi pengawas kegiatan tersebut, agar sesuai dengan harapan perguruan tinggi.

\section{b. Badan Konseling dan Psikologi Mahasiswa}

Unit ini nantinya berperan menyiapkan para tutor untuk disebar ke berbagai fakultas/jurusan selain itu berkontribusi sebagai pengarah kegiatan. Selain tutor BKP juga harus menyiapkan kurikulum yang sesuai dengan standar psikologi mahasiswa. Dengan fase awal melakukan riset terkait permasalahan mahasiswa berkenaan dengan program daring. Selain itu, nantinya dari pihak BKP akan membuat silabus kegiatan, setiap minggu serta indikator-indikator kognitif dan afektif kemahasiswaan.

\section{c. Peer konselor}

Organisasi ini dapat berkontribusi sebagai panitia agar kegiatan lebih mudah dipahami serta menjadi media informasi kepada mahasiswa lainnya. Mereka juga nantinya yang akan menjadi fasilitator kegiatan dan mentorisasi tentang self healing.

\section{Langkah Strategis untuk Mengimplementasikan Gagasan}

Berikut ini adalah penjabaran tahap-tahap dari pelaksanaan $\mathrm{H} 2 \mathrm{H}$ :

Tahap 1: Pengumpulan, pengolahan data dilanjut dengan pencetusan ide yang akan disampaikan kepada pihak UPT Badan Konseling dan Pembinaan Kampus.

Tahap 2: Diskusi dengan Badan Konseling Kampus, disertai dengan pematangan ide menjadi rencana yang kompleks dan matang. Selanjutnya, pada tahap ini dibentuk keapnitiaan tim serta pembuatan proposal resmi. Salah satunya membuat agenda transisi, analisis resiko, konsultasi dan persentasi proyek.

Tahap 3: Menggerakan pihak-pihak terlibat dan melaksanakan gagasan ini.

Tahap 4: Evaluasi, monitoring, dan pembelajaran. Segala bentuk masalah akan menjadi bahan evaluasi ke depan untuk perbaikan program ini.

\section{Kesimpulan}

$\mathrm{H} 2 \mathrm{H}$ (Here to Hear) merupakan gagasan yang bertujuan untuk memberikan kesadaran kesehatan mental pada mahasiswa. Program ini bermanfaat untuk mengurangi stres mahasiswa akibat beban perkuliahan daring dan kejenuhan 
melaksanakan karantina mandiri di rumah. Selain itu, program ini juga merupakan optimalisasi badan konseling kampus dalam rangka memberikan pelayanan psikologis bagi mahasiswa.

Pada dasarnya program ini adalah kegiatan terpadu berupa rangkaian mentorisasi, aplikasi, dan evaluasi yang untuk memberikan pendidikan kesehatan mental bagi mahasiswa. Dalam hal ini, setelah dimentorisasi maka mahasiswa akan melaksanakan praktik aplikatif yang bertahap berupa terapis aktivitas dan terapis meditasi. Untuk terapi aktivitas mahasiswa akan diajak melaksanakan kegiatan positif sesuai bidangnya masing-masing secara bertahap,. Untuk proses selanjutnya mahasiswa akan diajak secara serentak melaksanakan meditasi. Untuk selanjutnya, web/aplikasi daring digunakan untuk mempermudah pengawasan kegiatan, dimana fitur-fitur web berisi catatan agenda, hingga klaim penghargaan.

Here to Hear ini memerlukan dukungan segala pihak yang dapat mewujudkannnya. Dengan proses mental health attention, mahasiswa dapat mengurangi tingkat depresi akibat beban masalah di masa pandemi. Dalam $\mathrm{H} 2 \mathrm{H}$ mahasiswa diberi berupa treathment-treathment yang diperuntukan bagi mahasiswa. Badan konseling kampus memiliki peran sebagai pembina pelaksanaa program ini, dengan menghadirkan dosen ahli dan kurikulum pembelajaran.

Prediksi yang diharapkan adalah sebagai berikut :

1. Mengurangi tingkat stres mahasiswa akibat beban perkuliahan dari dan karantina mandiri di rumah.

2. Menyeimbangkan kesadaran mahasiswa akan kesehatan mental di masa pandemi Covid-19.

3. Mengarahkan kepada kegiatan positif di luar pembelajaran daring. 
Here To Hear: Metode Therapys Group dalam Proses Mental Health Attention untuk Menangani Stress Mahasiswa

\section{Bibliografi}

Arroisi, Jarman. (2018). Spiritual Healing dalam Tradisi Sufi. TSAQAFAH, 14(2), 323348.

Bahrien, Budiman, \& Ardianty, Septi. (2017). Pengaruh Efektivitas Terapi Self Healing Menggunakan Energi Reiki terhadap Kecemasan Menghadapi Ujian Skripsi. Psympathic: Jurnal Ilmiah Psikologi, 4(1), 141-148.

Fahrurrozi, A. M. (2019). MODEL PSIKOTERAPI DI KALANGAN MUSLIM BANTEN (ANALISA KUALITATIF DESKRIPTIF TERHADAP TERAPI KEJIWAAN PARA PRAKTISI DI KOTA SERANG). Al Qalam, 36(1), 21-36.

Florensa, Florensa, Keliat, Budi Anna, \& Wardani, Ice Yulia. (2016). Peningkatan Efikasi Diri dan Penurunan Depresi pada Remaja dengan Cognitive Behavior Therapy. Jurnal Keperawatan Indonesia, 19(3), 169-175.

Mufarida, Bina. (2020). Dampak Psikologis Corona Butuh Perhatian. Retrieved from https:/nasional.sindonews.com/read website: https:/nasional.sindonews.com/read

Purandina, I. Putu Yoga. (2020). Pendidikan Karakter Tumbuh Selama Pandemi Covid19. COVID-19: Perspektif Pendidikan, 99.

Shadiq, Rahyadi. (2020). Ini Pentingnya Konseling Online di Tengah Pandemi COVID19. Retrieved from https/beritabaik.id/read website: https/beritabaik.id/read

UNAIR. (2020). Departemen Piskologi Klinis.

Zu, Zi Yue, Di Jiang, Meng, Xu, Peng Peng, Chen, Wen, Ni, Qian Qian, Lu, Guang Ming, \& Zhang, Long Jiang. (2020). Coronavirus Disease 2019 (COVID-19): A Perspective from China. Radiology, 296(2), E15-E25. https://doi.org/10.1148/radiol.2020200490

Pengelola Web Kemdikbud.2020.”Mendikbud: Pandemi Ubah Cara Pandang Insan Pendidikan" dalam web kemdikbud. Kemdikbud.go.id. Diakses tanggal 19 September 2020.

Sulistyowati, Eko Endah.2009.Analisis Pelaksanaan Mentoring dalam Pembentukan Konsep Diri Pelajar SMA pada Lembaga ILNA YOUTH CENTRE BOGOR (Skripsi).UIN Syarif Hidayatullah. Jakarta. 